\title{
5. Layers of Being: Aspects of Researching and Writing Professional Savages: Captive Lives and Western Spectacle
}

\author{
Roslyn Poignant
}

My book, Professional Savages: Captive Lives and western Spectacle, was the outcome of a project that extended over many years in which I aimed to make sense of, and make a narrative of, what happened to a group of nine Manbarra and Biyaygirri Aborigines from North Queensland-Billy, Toby, Jenny, Tambo, Sussy, Jimmy, and the others - who were removed overseas by the showman R. A. Cunningham in 1883, and who toured extensively through America and Europe. By following the routes they had taken, and by drawing on sources, ranging from unreliable newspaper accounts of the period to culturally blinkered anthropological reports, as part of the process of interpretation, the visual material that I gradually assembled-photographs, circus ads, posters, newspaper sketches and cartoons-frequently functioned as crystallising images in which the dynamics of interaction were exposed, thereby shaping both the processes of 'looking for' - that is, the research-and the 'telling about' of their story. But first something about ego.

In early 2011, I attended a seminar in the October Gallery, London, led by three Indigenous Australian performance artists. One of the speakers, Fiona Foley, a Batjala woman from Fraser Island, referenced Professional Savages for the wellillustrated account it gave of the frontier wars in Queensland that had decimated her people and their more northerly neighbours. Afterwards, when she asked me why I had made so few references to my personal involvement in the story, I reminded her of the 'History Wars' of the 1990s and 2000s, and told her that I thought the best way to counter Keith Windshuttle's representation of the postcolonial rethinking of the colonial project as a Fabrication of Aboriginal History was with as carefully researched, detailed and non-partisan an account as possible. 


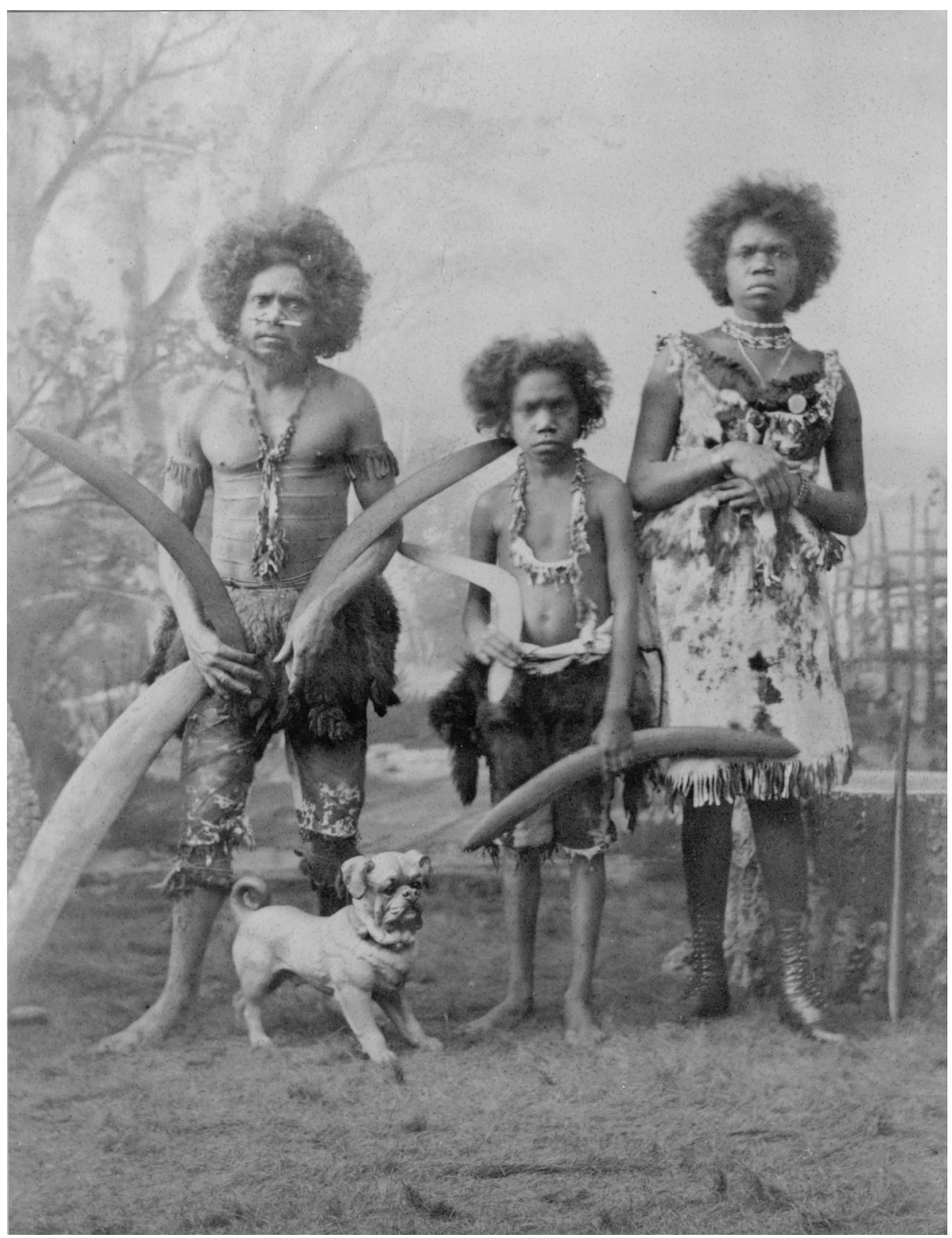

Billy, Jenny and her son Toby-the survivors of the group of nine removed from North Queensland-Paris, November 1885.

Source: Photograph by Prince Roland Bonaparte. Courtesy of the Royal Anthropological Institute, London. 
Fiona also asked me how and why I had become the teller of the story of Tambo and his companions. This was a question I had reframed for myself about halfway through my research in a note filed on my computer on February 12, 2001 as 'Layers $\mathrm{RP}^{\prime}$, 'as being not a simple matter of my self-imposed exile giving me insight into their displacement. It is more layered than that. An Australian exile in London is only one layer of my being. There are deeper layers of displacement in my family histories'. 'I can choose', I wrote, 'from a range of identities from Scottish Protestant, signalled by my name Roslyn, bestowed by my father who had migrated to Australia in the first decade of the twentieth century, to Jewish from my mother, whose forbears migrated to Australia from a shtetl in the Russian/Polish borderlands in the early nineteenth century, and settled in northern NSW, where my grandfather was a builder of hotels, hospitals and schools.' So I was personally aware of Jewish displacement and exclusion on account of race. More important, perhaps, an early awareness of difference had fuelled my curiosity about others. ${ }^{1}$ To take a different time and tack:

In 1969, my partner Axel and I arrived back in Sydney after a 13-year absence. For many months we had made our way slowly across the Pacific, staying and photographing in several different island communities. Wherever we went we encountered independence movements that were rippling out from the events of '68 in France and Europe. Flying on to Sydney, we found the Aboriginal Land Rights Movement in full swing. It was an exciting moment in history. On our first morning there I opened the paper and saw a photo of the artist Cristo and his wife, Jeanne-Claude, in the process of wrapping the rocky shoreline of Little Bay, a small sheltered cove just north of Botany Bay, Captain Cook's first landfall in Australia. The small beach at the foot of those cliffs was where I had spent some of the happiest hours of my childhood, and I saw the wrapping of a site of such personal significance to me as a gift: a welcome home to the place of my Dreaming. Little Bay lay several miles south of my childhood home in Maroubra, a straggling suburban encroachment on a shifting landscape of sand dunes and reedy swamps. A tramline, linking the inner city to the northern shore of Botany Bay, passed our front door, and then continued on past the concrete undulations of the speedway (a car-racing track) and the whitewashed walls and watchtowers of Long Bay Gaol, to the 'coast' hospital, leprosarium and quarantine station at the end of the line. There, in this liminal zone of Sydney, on the other side of the line, up the slope from Little Bay was the Aboriginal Reserve.

My father, who was a nurse at the hospital, had contact with the community, and one of my earliest memories is of his Aboriginal friend, Bill, who entertained

1 Docker identifies Leopold Bloom's 'diasporic consciousness' in Joyce's Ulysses as 'an attentiveness to other and previous histories, a worldly ease of reference and multiple habitation, a lack of fear of the elsewhere' (Docker 2001, p. 106). 
the crowds with his skill as a boomerang thrower. After a performance, Bill took us back to his humpy, a large domed structure made of curved branches and covered in pieces of canvas, where I was seated on an upturned bucket and given a mug of milky tea. There was also some conventional housing but during the worst depression years of the 1930s, many more Aborigines had drifted to Sydney from other districts in search of work, and had put up their temporary structures. A neighbouring gully, known as Happy Valley, was where the homeless unemployed set up their camps. Having now looked at the period photos online, I see it was even bleaker than the memory, remarkably accurate, of my five- or six-year-old self. ${ }^{2}$

A few years later, as times improved, an Art-Deco cinema was built across the tramline from us. On Saturdays the Aboriginal children would ride into Maroubra on the offside running board of the trams, out of reach of the conductors. Small dark figures would slide quietly behind the ushers into the cinema. Inside, all of us, Aboriginal and white kids, would riot up and down the aisles until the lights went down, then we would grab the nearest seats. When, a few years later, I stayed with family friends in the outer Sydney suburb of North Ryde, I was surprised to find there was a roped-off area for the Aborigines in the small open air cinema. As the lights went down they entered silently. Looking back, I recognise the distancing in both situations, for I had merely been one of the crowd.

Growing up in the economically tough 1930s, but having a sense of stability of family and place, my identity was also shaped by an awareness of being the product of two diasporas. I was also politicised by the depression and the arrival of refugees from Nazi oppression. Although my sister and I attended Presbyterian Sunday School, when I turned 12 in 1939 I decided not to be confirmed. It wasn't a matter of choosing between parental religions, but a conscious decision of my own made with the minister's encouragement. Nor was it a fixed position, but a shifting one that engendered a profound scepticism about all religions and a strong sense of justice. I was beginning to position myself as an outsider.

In time, this position also fuelled a curiosity about other cultures that would lead me to study history and anthropology at university. In 1947, in my final year, unable to choose between the two subjects, I undertook combined honours while 'majoring' in political protest. The issue was support for Indonesian independence, and our demonstration outside the Dutch Embassy was brutally broken up by Police Squad 21, which had been set up during the war to control the soldiers of several nations on leave in Sydney. It became a civil liberties

2 An extensive collection of over 200 photographs of Little Bay is available at http://www.photosau.com. au/Randwick/scripts/home.asp. 
issue, and my task as secretary of the University Labour Club was to gather statements from members of the public who had witnessed police violence (Barcan 2002). So I spent my days and nights divided between court hearings and the calm of the Mitchell Library, researching for my thesis. There in the quiet of the Library, inhaling the dust of disintegrating newsprint, I read an account of an aging Aboriginal man standing in downtown Melbourne, crying for his lost people and land - a powerfully haunting image to conjure up. It was also in that defining moment that I realised my future was in the archives and not in the streets. With the passage of time, I came to appreciate that the archive can also be a place for protest and resistance.

Unexpectedly, my combination of subjects, plus a strong interest in film, led to my first proper employment at the Commonwealth Film Division and thus began my lifelong engagement not only with film, but also still photography as both process and project, and, more particularly, since the 1970s, with a concern for the visual representations of 'the other' as a subject for interrogation and interpretation. This I pursued through publications and exhibitions, beginning with 'Observers of Man' in 1980 for the Royal Anthropological Institute, London. Included in that exhibition was a photograph of Billy, Jenny and her son Toby taken by Prince Roland Bonaparte in 1885 in Paris. At the same time the elder (husband and father) Toby was dying in a Paris hospital. In an already disturbing image, the point to which the eye is drawn is the stuffed dog in the foreground, undoubtedly placed there deliberately. The shock of this cruel visual pun on death and embalmment activates what Roland Barthes has described as 'the obtuse - as opposed to the obvious meaning ... Indifferent to moral or aesthetic categories it is on the side of carnival' (Barthes 1977, p. 55). As I have written elsewhere (Poignant 2004), it was the power of this particular image to compel an interrogative reading that launched my research project.

These three, Billy, Jenny and Toby, were the survivors of a group of nine North Queensland Aborigines removed abroad by the showman, Robert Cunningham. The first paper in which I attempted to tell their story more fully, Captive Aboriginal Lives: Billy, Jenny, Little Toby and their companions, was published by the Sir Robert Menzies Centre for Australian Studies, University of London, in 1993 (Poignant 1993). Writing in a milieu of involvement in activities of an Aboriginal Support Group in London, I addressed Aboriginal writer Henrietta Fourmiles' assertion that 'the hegemony of dominant culture continues to make Indigenous Australians captives of the archives and of discourse' (Fourmile 1989). I argued that 'the reclaiming of this suppressed history [of Aboriginal resistance to invasion] is urgent for all of us', and that '[t]here is also a sense 
in which archives are not the source, but the product of research; frequently they are formed in the process of ferreting out the evidence on the margins of history' (Poignant 1993, p. 43). ${ }^{3}$

My ferreting out of the details of the Aboriginal travellers' lives continued as a consequence of the entanglement of two projects. In the 1990s, I made several field trips to the Maningrida community in Arnhem Land by way of making cultural returns of Axel Poignant's photographs of the different language groups living in the area in the 1950s, the outcome of which, in 1996, was an exhibition and the book Encounter at Nagalarramba (Poignant \& Poignant 1996). Although unable to get funded support for the 'Captive Lives' project, on each of my exits from Arnhem Land I routed myself via North Queensland and then home to London across America, in order to follow their trail. Meanwhile, the small publication, Captive Aboriginal Lives, had made its way to Nicolaas Heijm, an anthropologist working with the Palm Island community, and in Brisbane in 1993 I at last made contact with Nick and Walter Palm Island. I had already learnt of a genealogical record made by the anthropologist N. B. Tindale that mentioned a brother of Walter's grandfather, Dick, who 'had gone to America for a show' and died there. ${ }^{4}$ This was the critical evidence that would later establish that Walter was a collateral descendant of Tambo. While we were together, I received news that the British Academy had come good with support for a research trip to America. So, by October, I had just arrived to research the circus collection in San Antonio, Texas, when a phone call came through from a newspaper in Cleveland, Ohio, with information about an Australian Aboriginal circus performer called Tambo. It seems, they said, his mummified body had been found in the basement of a funeral home in Cleveland. I won't retell the story of this serendipitous event here, except to say that the outcome-it seemed Tambo's special gift to me - was extra research time in America. Funded by the Aboriginal and Torres Strait Islander Commission's rapidly formed 'Bring Tambo Home' committee, I was able to stay on in America, continuing to research, while I waited for Walter Palm Island and his brother, Reg, to arrive in Cleveland and, after due ceremony, take their ancestor, Tambo, home.

Antonis Liakos has observed that, in history, writing our own experiences comes through like the rising damp surfacing through a newly painted wall. To paraphrase: It comes through, even as we write the experience of historical otherness; the more we try to separate our sympathies and antipathies, the more

\footnotetext{
3 'Ferreting' on the margins had also led me to write 'The Grid on Contested Ground' about the handover of Aboriginal skeletal remains from the Anatomy Museum at the University of Edinburgh, at Pickford's freight store, London Airport, in 1991, for The Olive Pink Society Bulletin, a short-lived journal concerned with 'the interaction of race and gender with the practices of Anthropology within Australia' (Poignant 1992).

4 Genealogical Sheet 63, Palm Island, Queensland, 28 October, 1938. Norman B. Tindale's papers, Museum of South Australia. Dick Palm Island (Walter's grandfather), born circa 1880, was about two when Tambo and the others were taken, so the knowledge would have been transmitted orally until Tindale wrote it down.
} 
we try to distance ourselves from our experience, the more it comes out from us in the writing of history (Liakos 2001). Obviously, I had begun my search for what happened to the Aboriginal travellers in the most accessible of the great libraries and archives. But as I extended the 'field' of my 'work' from the home places of Tambo and his companions in North Queensland to follow the routes of their journeys in America and Europe, I began to think of my research strategy as 'walking their walk': covering the same ground they had covered.

Although Guy Debord came up with the idea of psychogeography as a corollary to the 'society of the spectacle' (DeBord 2013), the relationship between the two became evident to me in the course of my research into the spectacle of the circus in America. This was especially so when I explored a town such as Bridgeport, once the winter quarters of Barnum \& Bailey's circus, and I noted on a postcard of the museum sent to a friend:

This surreality is a real building in a real street - not a model! It is set in a de Chirico townscape of elegant fortress bank buildings - the 19th century prosperity is over - and they are no longer occupied in deserted streets alongside the concreted wall of the elevated railway tracks. No signs or services on the station. At the foot of a graffitied stairway leading to the road I ran into a family of dwarfs (elevated disadvantaged). It seemed somehow only to be expected in the town where Tom Thumb had been born and raised. That was way back at the beginning of the journey. It has been like that all the way, a shadow journey, catching reflections from the past through a shattered and fragmented mirror. Tambo is only one piece ...

While travelling alone, sometimes chance factors, coupled with a tiny budget, exposed me to experiences that heightened my awareness of the existential predicament of the Aboriginal travellers in America. From time to time, I filed diary notes on my laptop where I teased out some of the researching/writing/ living issues that preoccupied me. Here are two extracts. The first, concerned with attitude and how to represent, was written sometime between mid-1993 and September of that year, just before leaving for the US:

I suppose in the way in which I relate to others - all others - I am locked into a-sort-of-voyeuristic engagement, the participatory nature of which foregrounds issues of ethics of representation. To write the seeing ' $I$ ' out of the narrative is to represent the mirror-field as if a portion of it has been obliterated by a retinal blind spot. To see, know, acknowledge oneself within the mirror-field is to represent, in varying degrees, autobiographically. Whatever the degree, is there any escape from the narcissistic trap? Is there life beyond the mirror? 
Fiction beckons. The refractory process. Yet, apart from the difficulties of how to make the fictional, the possibility of the trauma of betrayal remains contained within it. The very effectiveness of fiction - the projected image - depends on this dangerous edge of recognition and identification and on its power to reflect. There it is all done with mirrors. Is fiction perhaps the ultimate distancing mechanism? Or is all representation betrayal?

The second extract records experience and is written at the end of my stay in America, after the return of Tambo's body to Queensland. Titled "Dec. 12th New York", it is written after 8 December, 1993, when the ceremony for the release of Tambo's spirit took place in Cleveland, Ohio, followed by the repatriation of his body. After the Palm Islanders departed for Australia, I flew to New York, with only a few days before my plane left for London. Undecided about how to usefully advance my research in the remaining days, I wrote:

I'm too exhausted - emotionally drained to write it down [i.e. the events of the past few days in Cleveland]. I know I must risk not getting it down now. These are my last days in New York and choices to be made: Do I go to the New York Performing Arts to read New York clippers or to the Public Library to try a sampling of Californian papers? And back to Brooklyn for the clippings file. A choice between ruining my eyes on microfiche or microfilm. I opt instead for looking at techniques for printing the ads in the newspapers in an attempt to understand how printing techniques shaped the forms of representation. Who were the anonymous craftsmen in Cincinnati or Baltimore who took the cuts of newspaper entertainment ads and developed the circus ads, particularly for shows of Indigenous people?

One last day in the NY Public Library - by now I must look like a regular because the man next to me asked me how to adjust the machine.

[Later, in the same entry, I am describing the following day, 11 December.]

Outside it begins to sleet and snow ... On the way to the airport: the snow falls in great enveloping swirls of white out of a foggy sky. I sit straight behind the driver's radio listening to a constant commentary on the developing chaos at Kennedy airport ... 'Which way will I go', the disembodied voice asks. The reply cuts in 'there's only one way: Slow and easy'. The flight — all flights have been cancelled for 24 hours. The amenity desk helps me to book a bed at YMCA West 23rd St. I discover it is not a bit like West Central [where I had stayed on a previous occasion]. I pay for my bed, $44 \$$ ( $5 \$$ refund on the key). The lift is not working and a middle-aged black man quickly guides me on what he describes 
as a short-cut across a large unlit hall to the service lift. I am a late night gift. The possibility of earning something. The corridor walls are dark green and the cisterns from the lavatory block are running noisily. The room is shabby, but clean. The TV - as is usual - is suspended high up on the wall.

There are two pairs of metal, tiered, bunk beds, and a single bed. One lamp. I slip into bed trying to distinguish the street noises. Sleep fitfully. Read Toni Morrison. But it all comes flooding back to me. The strangeness of the way in which my journey shadows their journey. It is as if the disturbance of the surface uncovers and penetrates the deep layers. I tentatively grasp again the idea of 'fiction' or 'fact' - the notion of a shared history. The reach of the imagination required. It is as if the difficulties of my journey bring me in touch with the experiences of their journey. Should I allow myself to be submerged in the experience so deeply?

I switch on the television:

'Prime Time. Keeping you connected to those you care about.'

Obsessive compulsion of the flow of ads. 'Five have died in a Long Island train massacre ...', we are told. Apparently the shoot-out took place Tuesday last (Dec 7th) the same day as Tambo's ceremony. They are interviewing people in the street about stricter gun control laws. Then comes: A pink doll in a walking frame. She giggles as she bounces. I switch her off and try to go to sleep. Night cries from the street enter my dreams. I switch the light on and see a cockroach scuttling along the top bed rail of the two-tiered-bunk on the other side of the room.

Daylight - 7.30 or 8 am I go down to telephone the airline. Yes, the plane will go at $2 \mathrm{pm}$, but I should get to the airport. And why not? There's not much else to do. I walk the corridors, lugging my bag up and down runs of stairs, until I find myself in the proper entrance hall that I'd missed the night before. There is a queue of about a dozen people, mostly men, in a subdued and orderly line at the desk. A tired man sits there dispensing soap and towel for a few coins, as they shuffle by. I haven't the gall to recover my five dollars for the key. Pushing the bag ahead of me onto the broken ice of the deserted street, and past the boarded-up housing estate, I come to a main thoroughfare on which the traffic is going uptown. I wait a long time before a taxi picks me up. 
After America, I knew the story-gathering was incomplete and I wanted to get on with the research of what happened to the Aboriginal travellers in Europe, but the pressure for a piece of public history-telling was too great. The outcome was the 'Captive Lives' exhibition for the National Library of Australia in 1996. One strand of the exhibition sought to recover the individual identities of the Aboriginal travellers from performance roles. The other examined the mechanisms of their obliteration, particularly the consolidation, by the late nineteenth century, of the savage stereotype, which was imprinted both through performance, in what I called the 'show-space', and in graphic and photographic forms of representation, examples of which I had assembled along the way.

Key to the development of the exhibition was the Library's agreement to the appointment of four Indigenous advisors, each one representing one of the related language groups from which the Aboriginal travellers had come, led by Walter Palm Island, who was representing both his family and the Manbarra of Palm Island. Certainly, one of the most emotionally difficult things I have ever done - though also among the most rewarding - was to take the layout of the whole exhibition back to the Palm Island community, where it was discussed by a large gathering of the residents. The experience of removal, and the fear of it, loomed large in the collective memory of everyone present and, one after the other, they began, quietly and with dignity, to testify to personal recollections and experiences of removal from Aboriginal communities throughout Queensland to Palm Island. Yes, they wanted this earlier history of removal to be told. The meeting went on for the best part of the day.

After Canberra, the exhibition toured widely, including several centres in Queensland, and it has had an afterlife as a permanent installation at the Aboriginal Centre, Mungalla, the heartland of the Nyawaygi-speaking clans on Halifax Bay, Queensland. In the 1990s, Australia seemed to be at an historical moment of reformulation of national identity, central to which was an endeavour, as a community, to forge a new contract with the original owners of the land. But such moments are difficult to sustain in the face of continuing prejudice. In 1998, the London Sunday Times published a feature article about the high suicide rate of the young men of Palm Island, which they described as the 'most violent place on Earth' and 'Devil's Island' (Scott \& Levy 1998, pp. 14-25). Without concern for the inaccuracy of the statistics they printed, or for historical accuracy, the writers chose to frame their story, 'This Spectred Isle', within a retelling of Tambo's removal and the apparent return of his ghost. The picture editor obligingly provided a red image of the ghost by digitally manipulating the photo of Jimmy, not Tambo, copied from the 'Captive Lives' exhibition broadsheet (Scott \& Levy 1998, p. 14). Photographic manipulation has always featured as a visual narrative device, and the issues, as always, are to do not only with aesthetics but also ethics, moral rights, and power 
relations. The digitised transformation of a nineteenth century photograph had facilitated the persistence of an old stereotype of savagery in the service of continued discriminatory practices: the careless demonisation of an Aboriginal community. My protests to the Murdoch press went largely unsupported, even by institutions that had hosted the exhibition.

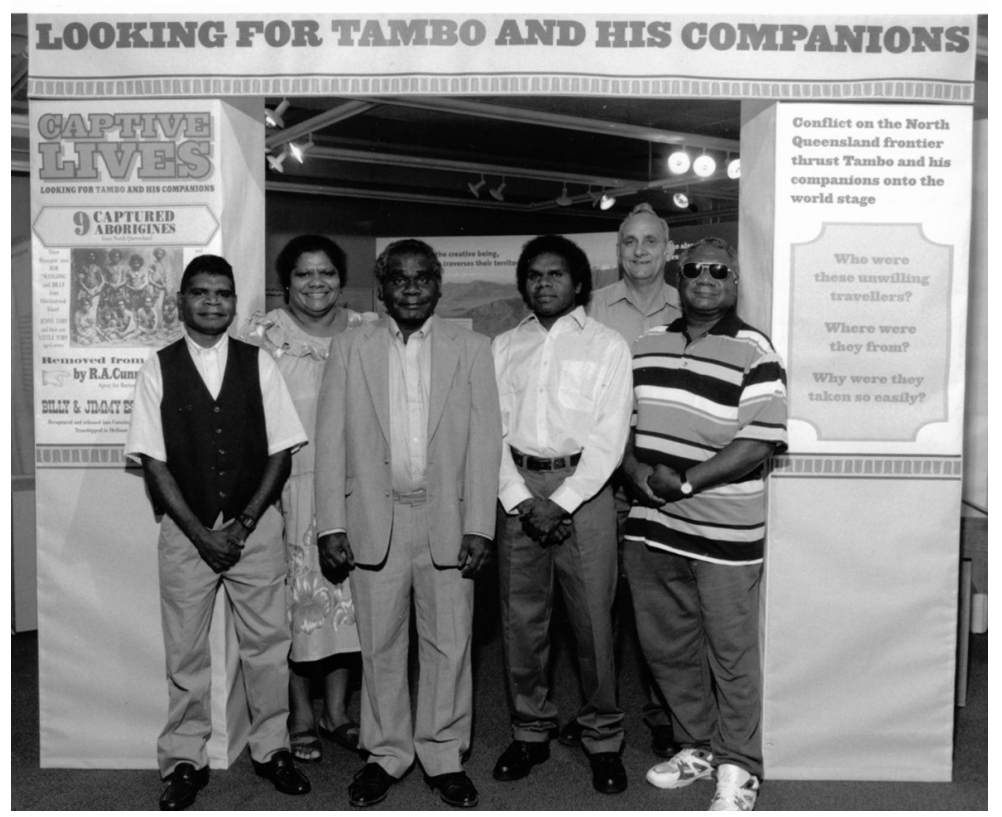

Captive Lives exhibition opening at National Library, Canberra 1996. From left to right: Alan Palm Island, Josephine Giea, Walter Palm Island, Reg Palm Island, Ernest Grant and Maurice Bligh.

Source: Photograph by Louis Seselja. Courtesy of the National Library of Australia, exhibition section.

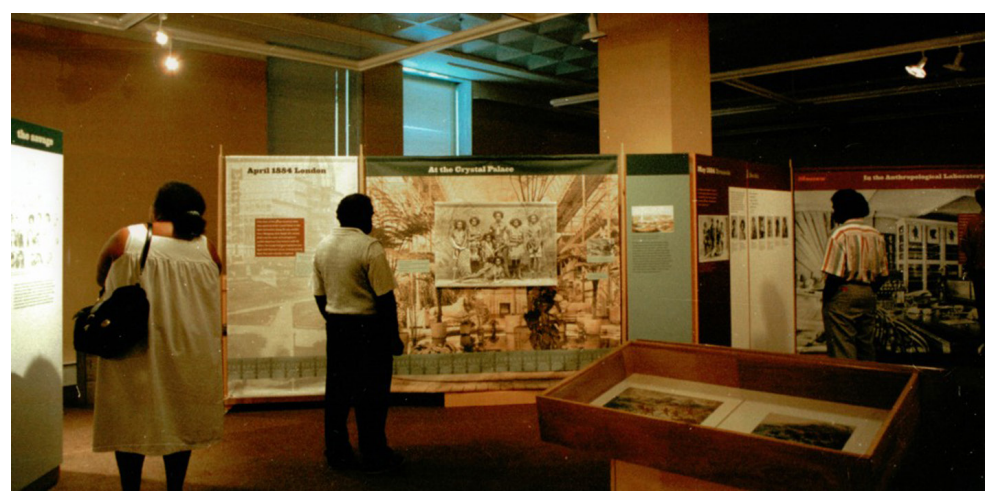

The Palm Island delegates visiting the Captive Lives exhibition.

Source: Photograph courtesy of Roslyn Poignant. 
In spite of the exhibition, from my point of view the story of the Aboriginal travellers remained incomplete. It was not until after 2000 that I was able to obtain funding to pursue what happened to the ever-diminishing group of Aboriginal travellers in Europe, where their transformation into professional show people was completed as they honed their performance skills. Indeed, for me, there was no sense of closure until 15 September, 2000, when, on an unusually warm autumn day, I sat in the sunshine in a cemetery in Darmstadt by some marker stones that indicated the spot where Jimmy had once been buried. Cemetery documentation showed that his remains had long since been removed to a communal burial area. ${ }^{5}$ Nearby was a line of taps and a row of watering cans on hooks, all around me people were quietly tending graves. I absorbed the quiet beauty of the spot where Jimmy had been laid to rest by strangers. Jimmy, who had made my search for what happened to the Aboriginal traveller seem not only possible but irresistible, when I so easily found the record of his death in the Registry of Deaths Abroad, in the British Registry Office in the early 1990s.

\section{Acknowledgements}

My thanks to a younger generation of scholars who welcomed me to their conference in December 2011. Thanks also to my patient readers, Christopher Wright, Ian Henderson and Lynette Russell. Thanks always to the Indigenous advisers for the 'Captive Lives' exhibition, Walter Palm Island, Reg Palm Island, Maurice Bligh, the descendants of the original travellers, and to Josephine Giea, Ernest Grant and Nicolaas Heijm.

\section{References}

Barcan, A 2002, Radical Students: The old left at Sydney University, Melbourne University Press, Melbourne.

Barthes, R 1977, Image, Music, Text, translated by Stephen Heath, Fontana Press, London.

DeBord G 2013, The Society of the Spectacle, Notting Hill Editions, London.

Docker, J 2001, 1492: The Poetics of Diaspora, Continuum, New York.

5 In Germany grave sites are usually cleared after 25 years. I was reassured that, in this case, the rate of decay was related to soil composition. 
Foley, F (ed.) 2006, The Art of Politics the Politics of Art: The place of indigenous contemporary art, Keeaira Press, Brisbane.

Fourmile H 1989, 'Who Owns The Past?: Aborigines as captive of the archives', Aboriginal History, vol. 13, no. 1.

Liakos, A 2001, 'History Writing as the Return of the Repressed', Historein, vol. 3, pp. 47-58.

Poignant R 2004, Professional Savages: Captive lives and western spectacle, Yale University Press, New Haven.

Poignant R 1993, 'Captive Lives: Australian captivity narratives', in K DarianSmith K, R Poignant \& K Schaffer, working papers in Australian studies no. 85-87, Sir Robert Menzies Centre for Australian Studies, University of London.

Poignant R 1992 'The Grid on Contested Ground', The Olive Pink Society Bulletin, vol. 4 , no. 1 .

Poignant R and Poignant A 1996, Encounter at Nagalarramba, National Library of Australia, Canberra.

Scott, C C \& A Levy 1998, 'This Spectred Isle', Sunday Times, 1 February, 1998. 
This text taken from Ngapartji Ngpartji: In turn in turn:

Ego-histoire, Europe and Indigenous Australia

Edited by Vanessa Castejon, Anna Cole, Oliver Haag and Karen Hughes,

published 2014 by ANU Press, The Australian National University, Canberra, Australia. 